\title{
Biologinio vaisto Mepolizumabo poveikis gyvenimo kokybei ir plaučių funkcijai sergant sunkia eozinofiline astma: MUSCA tyrimo duomenys
}

\author{
EFFECTS OF BIOLOGIC DRUG MEPOLIZUMAB ON HEALTH-RELATED QUALITY OF \\ LIFE AND LUNG FUCTION IN SEVERE EOSINOPHILIC ASTHMA: MUSCA STUDY DATA
}

VIRGINIJA KALINAUSKAITĖ-ŽUKAUSKĖ

LSMU MA Pulmonologijos klinika

Santrauka. Ilgalaikio astmos gydymo tikslas - pasiekti simptomų kontrolę, sumažinti paūmèjimų riziką, bronchu obstrukcija ir su vartojamais vaistais susijusius nepageidaujamas reakcijas. Ne mažiau svarbu gerinti su sveikata susijusia gyvenimo kokybę. Sergančiuju sunkia eozinofiline astma gyvenimo kokybès gerinimas prilygsta iššūkiui, nes eozinofilinei astmai būdingi pasikartojantys paūmèjimai, bloga ligos kontrolè, sparčiai blogéjanti plaučiu funkcija, blogéjanti su sveikata susijusi gyvenimo kokybè. Pastebèta, kad, gydant mepolizumabu - anti-IL-5 monokloniniu antikūnu, - gyvenimo kokybè reikšmingai pagerèja, o pats gydymas saugus. Todèl šie rezultatai rodo, kad mepolizumabo pridejimas prie standartinio astmos gydymo gali turèti reikšminga teigiama poveikį.

Reikšminiai žodžiai: sunki eozinofiliné astma, IL-5, anti-IL-5 monokloninis antikūnis, su sveikata susijusi gyvenimo kokybè.

Summary. The long-term goals of asthma management are to achieve good symptom control, and to minimise any future risk of exacerbations, fixed airflow limitation, and side effects of treatment. Improving patients' health-related quality of life (HRQOL) is also important. Improving HRQOL is of particular interest in severe eosinophilic asthma, which is characterised by recurrent exacerbations, poor disease control, accelerated lung function decline, and decreased HRQOL. Mepolizumab - anti-IL-5 monoclonal antibody - was associated with significant improvements in HRQOL in patients with severe eosinophilic asthma, and had a safety profile similar to that of placebo. These results add to and support the use of mepolizumab as a favourable add-on treatment option to standard of care in patients with severe eosinophilic asthma.

Key words: severe eosinophilic asthma, IL-5, anti-IL-5 monoclonal antibody, health-related quality of life.

\section{IVADAS}

Visame pasaulyje astma serga apie 358 milijonai žmonių. Tinkamai gydant daugeliui jų astmos simptomus pavyksta kontroliuoti. Deja, nustatyta, kad 5-10 proc. sergančiųjų astma pasireiškia sunki ligos forma, jos simptomus kontroliuoti sunku, o astmos priepuoliai kartojasi netgi vartojant dideles vaistuc dozes [1]. Ilgalaikio astmos gydymo tikslas - pasiekti simptomų kontrolę, sumažinti paūmèjimų riziką, bronchų obstrukciją ir su vartojamais vaistais susijusias nepageidaujamas reakcijas. Ne mažiau svarbu gerinti su sveikata susijusią gyvenimo kokybę [2]. Sergančiụjų sunkia eozinofiline astma gyvenimo kokybès gerinimas prilygsta iššūkiui. Biologinis vaistas mepolizumabas gali būti veiksmingas sergant sunkia eozinofiline astma, pasireiškiančia pasikartojančiais paūméjimais, bloga simptomų kontrole, greitu plaučių funkcijos mažèjimu, kaip pridètinis gydymas greta simptomus slopinamụjų ir kontrolinių astmos gydymui skiriamų vaistų.

\section{SUNKI ASTMA}

Sunki astma - tai astma, kurią reikia gydyti didele inhaliuojamujų kortikosteroidų (IKS) doze kartu su kitu simptomus kontroliuojamuoju vaistu ir (arba) sisteminio poveikio kortikosteroidais, norint išvengti nekontroliuojamos astmos, arba būklè išlieka nekontroliuojama, nepaisant skiriamo gydymo [6]. Sergantiesiems dažnai priskiriami ir tie pacientai, kurie ilgą laiką vartoja geriamuosius kortikosteroidus (GKS). Kai kuriems sunkia astma sergantiems pacientams randamas padidejęs eozinofilų kiekis plaučiuose, sukeliantis uždegimą, veikiantį kvèpavimo takus, todèl blogèja plaučių funkcija, dažnėja astmos priepuolių skaičius $[3,4]$. Kadangi pagrindinis eozinofilų dauginimosi, aktyvinimo ir išgyvenimo bei eozinofilų judejjimo iš 
kaulų čiulpų ì plaučius mediatorius yra interleukinas 5 (IL-5) [4-7], jo slopinimas galètų reikšmingai pagerinti sergančiojo būklę, o kartu ir su gyvenimo kokybe susijusią sveikatą.

\section{MUSCA TYRIMAS}

Atliktas atsitiktinių imčių, dvigubai aklas, placebu kontroliuojamas, paralelinių grupių, daugiacentris, $3 \mathrm{~b}$ fazès klinikinis tyrimas MUSCA (angl. Mepolizumab

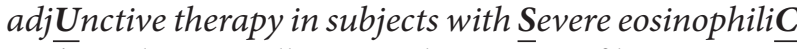
$\underline{A}$ sthma, liet. pagalbinis sunkios eozinofilinès astmos gydymas mepolizumabu) [8], kuriame vertintas biologinio vaisto Mepolizumabo ${ }^{\oplus}$ ) - IL-5 slopintojo-veiksmingumas ir saugumas.

Tyrimas MUSCA vykdytas 146 ligoninèse ir tyrimu centruose 19 valstybių visame pasaulyje, įskaitant Argentiną, Belgiją, Bulgariją, Kanadą, Čekiją, Estiją, Prancūziją, Vokietiją, Graikiją, Italiją, Nyderlandus, Norvegiją, Peru, Rusijos Federaciją, Slovakiją, Ispaniją, Ukrainą, Jungtinę Karalystę ir Jungtines Amerikos Valstijas. Tyrime dalyvavo ne jaunesni kaip 12 metu asmenys $(n=551)$, sergantys sunkia eozinofiline astma, per pastaruosius metus iki ịtraukimo ị tyrimą
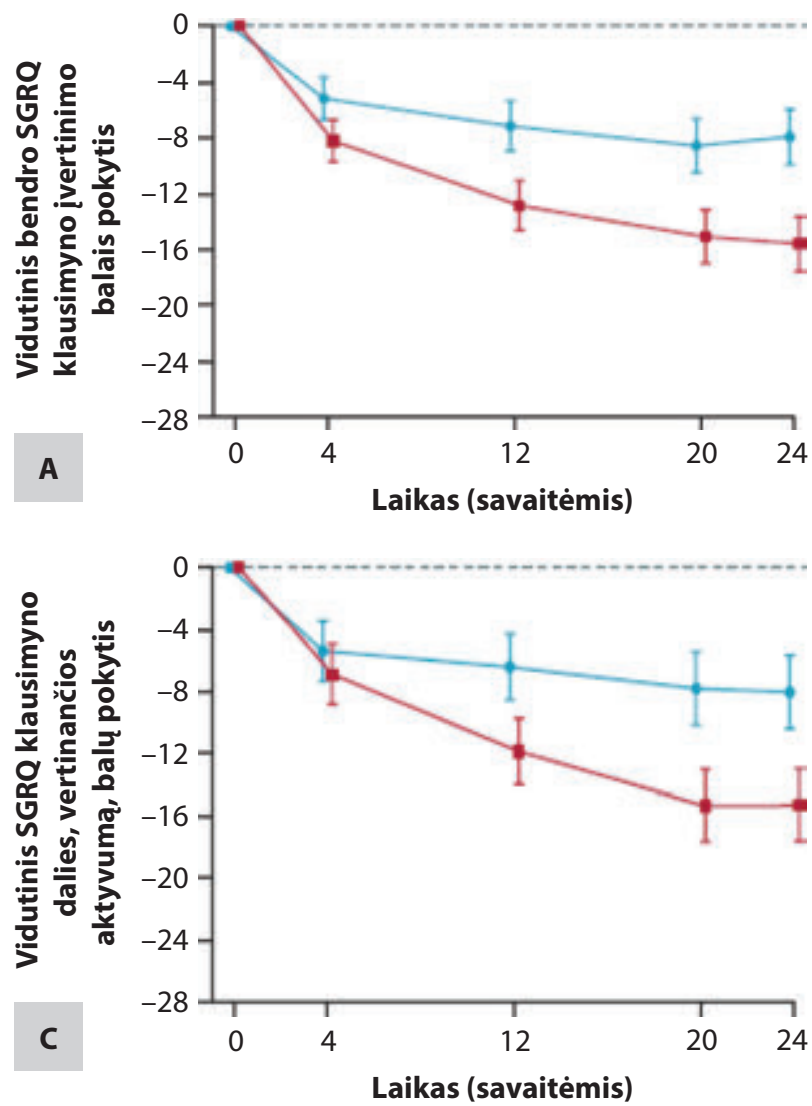

- Mepolizumabas patyrę ne mažiau du astmos paūmejjimus, nepaisant nuolatinio didelių dozių inhaliuojamųjų kortikosteroidų vartojimo kartu su kitais kontroliniais vaistais. I tyrimą neịtraukti rūkantys asmenys arba anksčiau bent 10 penkmečių rūkę asmenys. Tiriamieji atsitiktine tvarka (1:1) buvo suskirstyti ì placebo arba $100 \mathrm{mg}$ mepolizumabo grupes, leidžiant po oda placebą arba tiriamąji vaistini preparatą kas keturias savaites iki bendros 24 savaičių gydymo trukmès. Tyrimo metu papildomai prie skiriamo astmos gydymo buvo skiriamas mepolizumabas 274 tiriamiesiems, placebas - 277 .

Tyrimo pirminè vertinamoji baigtis buvo gyvenimo kokybès vertinimas balais pagal SGRQ po 24 gydymo mepolizumabu savaičių [1]; pagrindinès antrinės vertinamosios baigtys (vertintos 24 gydymo mepolizumabu savaitę) - plaučių funkcijos pokytis, vertinant forsuoto iškvėpimo tūrị per pirmą sekundę (angl. Forsed Expiratory Volume in $1^{\text {st }}$ second, $\mathrm{FEV}_{1}$ ) prieš inhaliuojant bronchus plečiamuosius vaistus; tiriamųjų skaičius, kuris pagal SGRQ turèjo gerą atsaką ị skiriamą gydymą ( $\geq 4$ balų pokytis lyginant su pradiniu SGRQ įverčiu); vidutinis penkių dalių Astmos kontrolès klausimyno (angl. Asthma Control Questionnaire-5; ACQ-5) balų
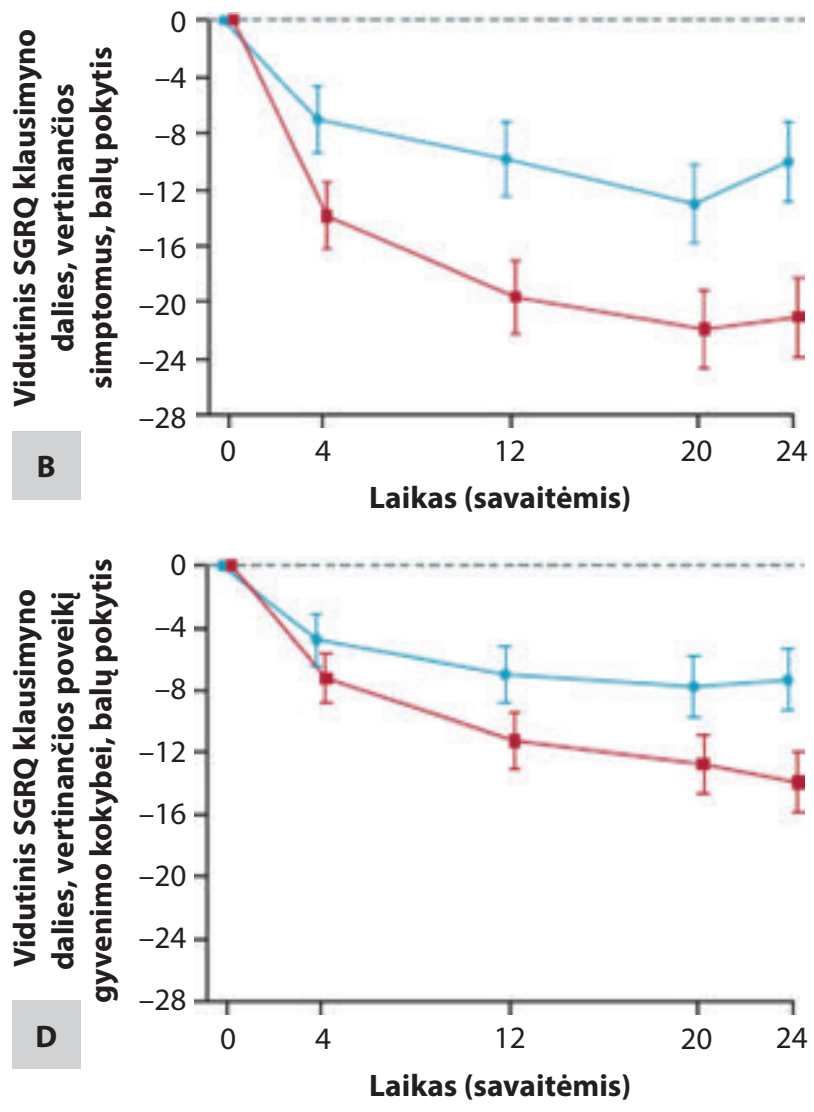

Placebas

1 pav. Šv. Jurgio Kvèpavimo klausimyno vertinimas balais kiekvieno vizito metu [8]

Paveiksle pateikiami koreguoti vidutiniai pokyčiai (95 proc. pasikliautinasis intervalas, PI) lyginant su pradiniu: A) bendras SGRQ balas; B) Klausimyno dalies, vertinančios simptomus, balas; C) Klausimyno dalies, vertinančios aktyvumą, balas; D) Klausimyno dalies, vertinančios poveiki gyvenimo kokybei, balas Santrumpos: SGRQ - švento Jurgio kvèpavimo klausimynas (angl. St. Georges Respiratory Questionnaire) 


\section{Farmakoterapija}

pokytis. Ne mažiau svarbus buvo ir saugumo profilio vertinimas.

Tyrimas MUSCA - tai pirmas klinikinis tyrimas suplanuotas taip, kad pirmiausiai būtų įvertintas mepolizumabo poveikis su liga susijusiai gyvenimo kokybei sunkia eozinofiline astma sergantiems pacientams. Su sveikata susijusi gyvenimo kokybė vertinta naudojant Šv. Jurgio Kvėpavimo klausimyną (angl. the St. Georges Respiratory Questionnaire (SGRQ)). Pateikus keletą SGRQ klausimų, ì kuriuos pacientai turèjo atsakyti savarankiškai, nustatyta, kokią ịtaką paciento astmos simptomai daro kasdienei veiklai, pav., vaikščiojimui, namų ruošai, ejjimui ị parduotuves, sodininkystei arba lengvam fiziniam krūviui, ar sunki astma trukdo jiems užsiimti veikla, kuria jie kitais atvejais galètų užsiimti.

Analizuotant MUSCA tyrimo rezultatus, nustatyta, kad gyvenimo kokybè pagal SGRQ po 24 gydymo savaičių (pagrindinė vertinamoji baigtis) buvo ịvertinta 7,7 balo geriau už pradinę, palyginus su placebo grupe $(\mathrm{p}=0,001)$, - beveik dukart daugiau už apibrèžtą kliniškai reikšmingą 4,0 balų arba didesnị skirtumą (1 pav. A-D). Plaučių funkcijos (pirmoji
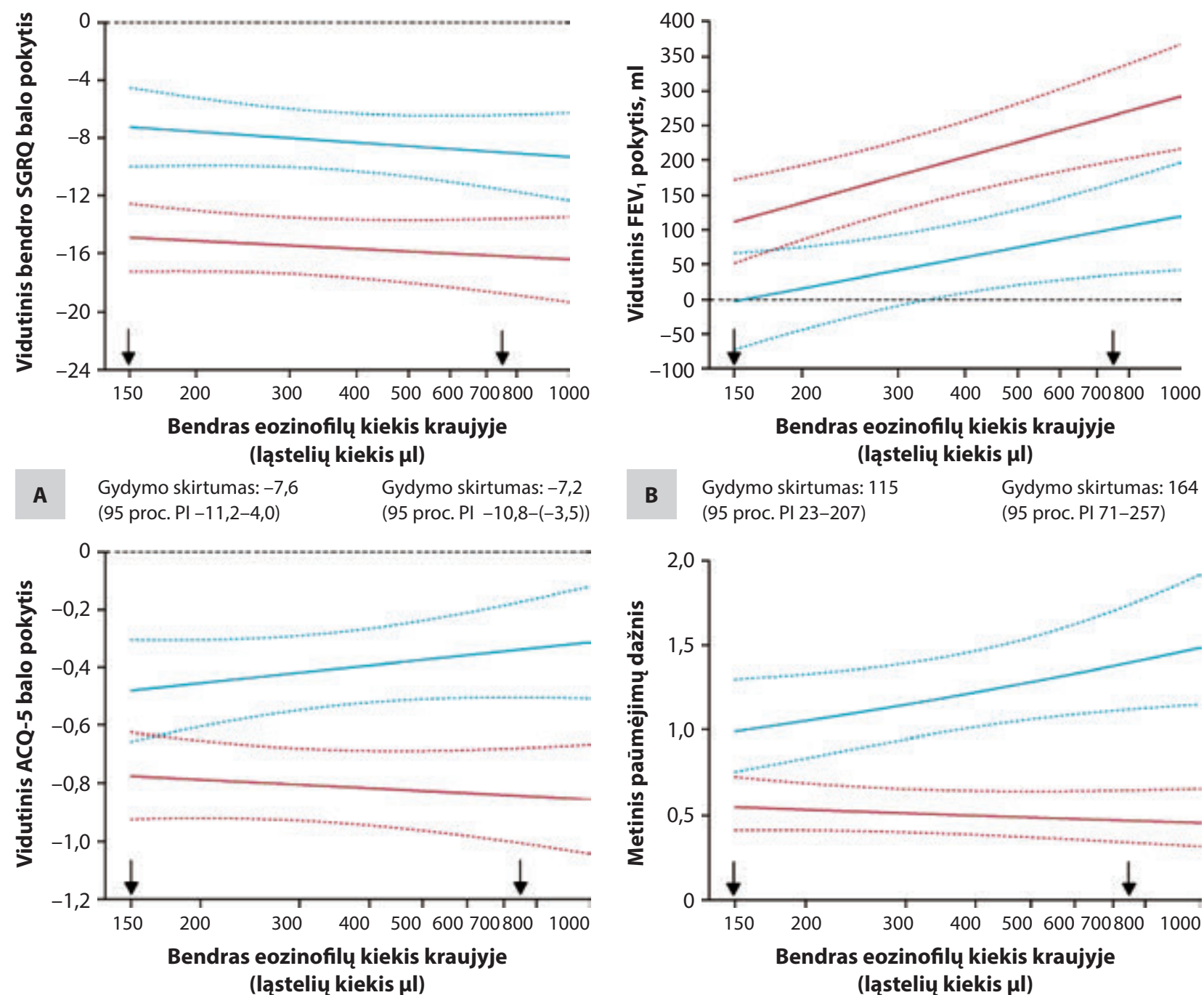

Gydymo skirtumas: $-0,29$

(95 proc. PI $-0,52-(-0,06)$ )
Gydymo skirtumas: $-7,2$ (95 proc. PI $-10,8-(-3,5)$ )

Gydymo skirtumas: $-0,50$ (95 proc. PI $-0,81-(-0,27)$ )

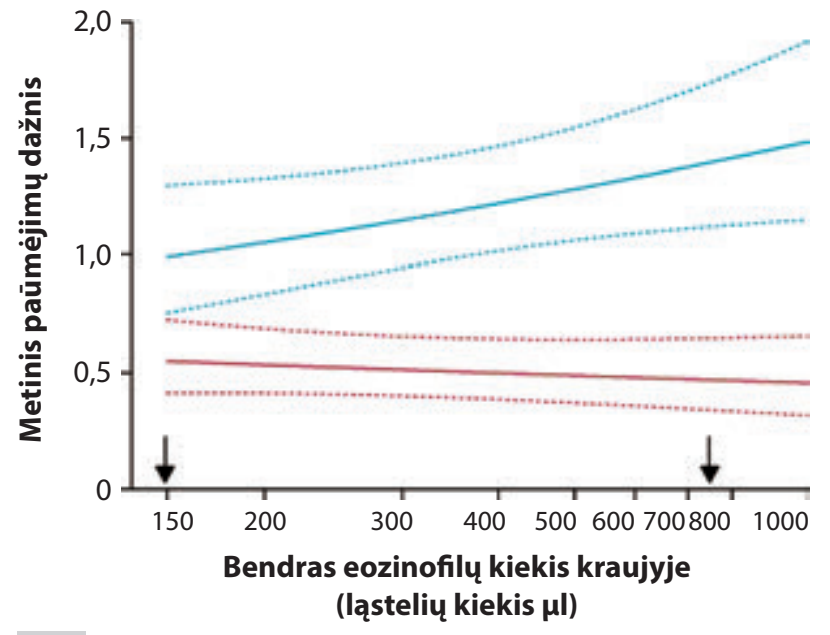

D Gydymo skirtumas: 0,55 (95 proc. PI 0,38-0,81)

Gydymo skirtumas: 0,33 (95 proc. PI 0,23-0,49)

\section{- Mepolizumabas —Placebas}

\section{2 pav. MUSCA tyrimo vertinamujų baigčių pokyčiai lyginant su pradiniais duomenimis [8]}

Duomenys pateikiami kaip koreguotos prognozuojamų pokyčių vidutinès reikšmès (95 proc. PI) lyginant su pradiniais duomenimis: A) bendras SGRQ balas; B) FEV $_{1}$ reikšmè prieš bronchus plečiamujų vaistų inhaliaciją; C) bendras ACQ-5 balas; D) prognozuojamas vidutinis metinis astmos paūmèjimų dažnis (95 proc. PI) - pagal pradini eozinofilu kieki kraujyje.

Ištisinės linijos rodo numatomus vidutinius pokyčius nuo pradinio lygio, taškinès linijos - 95 proc. PI vršutinę ir apatinę ribas. Gydymo skirtumai nustatyti 150 ir 750 ląstelių viename $\mu \mathrm{L}$ intervale.

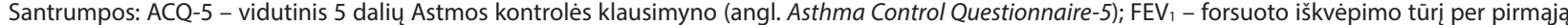
sekundę (angl. Forsed Expiratory Volume in 1rst second); PI - pasikliautinasis intervalas; SGRQ - Šv. Jurgio Kvèpavimo klausimynas (angl. St. Georges Respiratory Questionnaire). 


\section{Farmakoterapija}

antrinè vertinamoji baigtis), įvertintos pagal $\mathrm{FEV}_{1}$ prieš vartojant bronchų plečiamuosius vaistus, pagerèjimas 24-ąją gydymo savaitę buvo $120 \mathrm{ml}(\mathrm{p}=0,001)$ didesnis nei vartojant placebą (kliniškai ir statistiškai reikšmingas pagerèjimas). $\mathrm{FEV}_{1}$ ir SGRQ balai buvo vertinami tyrimo metu ir pagerejjimas, kuris išliko visą 24 savaičių tiriamąji laikotarpị, buvo pastebètas jau per pirmąsias keturias gydymo mepolizumabu savaites (2 pav. A, B). Naudojant ACQ-5, nustatytas reikšmingas astmos kontrolès pagerẻjimas (papildoma antrinè vertinamoji baigtis) 0,40 vieneto gydymo mepolizumabu grupeje, palyginus su rezultatais gautais vartojant placebą ( $<<0,001)$ ( 2 pav. C). Tyrimo metu pastebèta, kad gydant mepolizumabu, pasiekiamas greitas ir išliekantis su sveikata susijusios gyvenimo kokybės pagerejimas [8].

Taip pat nustatyta, kad vidutinis metinis kliniškai reikšmingų astmos paūmèjimų skaičius sumažèjo 58 proc., paūmèjimų, dèl kurių teko apsilankyti skubiosios pagalbos skyriuje arba gydytis ligoninejje skaičius, kuris mepolizumabu gydytų žmonių grupeje - 68 proc., palyginus su placebo grupe [8] (2 pav. D). Šie duomenys yra panašūs ị registracinio III fazès tyrimo MENSA analogiškus duomenis [10].

Be to, buvo ivertintas saugumas: MUSCA tyrimo metu gauti gydymo mepolizumabu saugumo duomenys atitiko duomenis, pateiktus Nucala preparato registraciniuose dokumentuose [8,9]. Dažniausiai MUSCA tyrimo metu fiksuotos nepageidaujamos reakcijos buvo galvos skausmas ir nazofaringitas. Sisteminių ir lokalių dūrio vietos nepageidaujamų reakcijų skaičius buvo panašus tiek skiriant papildomai placebą, tiek mepolizumabą. Tyrimo metu mirčių neužfiksuota. Todèl vaistas laikomas saugiu.

\section{KORTIKOSTEROIDU DOZĖS MAŽINIMAS}

Pradejus gydymą mepolizumabu (Nucala ${ }^{\circledast}$ ), sisteminio poveikio arba inhaliuojamųjų kortikosteroidu (IKS) vartojimo staiga nutraukti negalima. Kortikosteroidų dozes, jeigu galima, reikia mažinti palaipsniui, prižiūrint gydytojui. Kortikosteroidų dozès sumažinimas gali būti susijęs su sisteminiais nutraukimo simptomais ir (arba) būklių, kurios anksčiau buvo nuslopintos sisteminiais kortikosteroidais, pasireiškimu.

Nucala negalima gydyti ūminių astmos simptomų, astmos paūmèjimo arba ūminio bronchų spazmo.

\section{APIE NUCALA ${ }^{\oplus}$}

Nucala ${ }^{\oplus}$ yra pirmasis biologinis vaistas, kuris priklauso IL-5 slopinamųjų vaistų grupei. Vaistas buvo specialiai sukurtas gydyti sunkia astma sergančius pacientus, kurių būklè yra susijusi su eozinofilų su- keltu uždegimu. Nucala ${ }^{\oplus}$ prisijungia prie signalinio baltymo IL-5 ir neleidžia jam prisijungti prie eozinofilų paviršiuje esančių receptorių. Dẻl IL-5 prisijungimo slopinimo mažèja eozinofilų koncentracija kraujyje, audiniuose ir skrepliuose. Tačiau mepolizumabo veikimo mechanizmas sergant astmą nepakankamai ištirtas.

Nucala (100 mg mepolizumabo fiksuotosios dozès injekcija po oda) yra registruotas vaistas Europos Sąjungoje pacientų, kuriems diagnozuota sunki atspari eozinofilinè astma, papildomam gydymui.

\section{APIBENDRINIMAS}

MUSCA tyrimo duomenimis, gydymas Nucala ${ }^{\oplus}$ (mepolizumabu), palyginus su placebu, kliniškai ir statistiškai reikšmingai pagerina sunkia astma sergančių pacientų, kurių ligą sukèlė eozinofilinis uždegimas, su sveikata susijusią gyvenimo kokybę ir plaučių funkciją, suretino metinị astmos paūmèjimų dažnị. Šie duomenys apie pirmąji šios grupès biologinị vaistą buvo gauti gydant pacientus, jau vartojusius îprastos priežiūros vaistus. Mepolizumabo saugumas panašus i placebo, todèl $\mathrm{Nucala}^{\circledast}$ saugu skirti papildomam sunkios eozinofilinès astmos gydymui.

Straipsnio publikaciją remia sveikatos priežiūros bendrove „GlaxoSmithKline Lietuva“

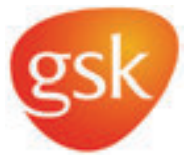

LT/NLA/0019/17, paruošta 201709

\section{LITERATŨRA}

1. Chung KF et al. International ERS/ATS guidelines on definition, evaluation and treatment of severe asthma. Eur Respir J, 2014;43:343-73.

2. Jones PW, Quirk FH, Baveystock CM et al. A self-complete measure for chronic airflow limitation - the St George's Respiratory Questionnaire. Am Rev Respir Dis, 1992; 145:1321-27.

3. Rothenberg ME. Eosinophillia. N Engl J Med, 1998;338:15921600 .

4. Malinovschi A et al. Exhaled nitric oxide and blood eosinophils independently associate with wheeze and asthma events in NHANES subjects. J Allergy Clin Immunol, 2013;132:821-27.

5. Lopez AF et al. Recombinant human interleukin 5 is a selective activator of human eosinophil function. J Exp Med, 1988; 167:219-24.

6. Rosenberg HF, Dyer KD, Foster PS. Eosinophils: changing perspectives in health and disease. Nat Rev Immunol, 2013;13:9-22.

7. Kouro T, Takatsu T. IL-5- and eosinophil-mediated inflammation: from discovery to therapy. Int Immunol, 2009; 21:1303-09.

8. Chupp GL, Bradford ES, Albers FC et al. Efficacy of mepolizumab add-on therapy on health-related quality of life and markers of asthma control in severe eosinophilic asthma (MUSCA): a randomised, double-blind, placebo-controlled, parallel-group, multicentre, phase $3 \mathrm{~b}$ trial. Lancet Respir Med, published online April 5, 2017.

9. Nucala SmPC, 2016.

10. Ortega HG et al. Mepolizumab treatment in patients with severe eosinophilic asthma. N Engl J Med, 2014; 371:1198-07. 